\title{
AGRO-MANAGEMENT PRACTICES FOR SUSTAINABLE WHEAT PRODUCTION UNDER SCARCE WATER CONDITION OF ARID CLIMATE
}

\author{
Hakoomat Ali ${ }^{1}$, Nadeem Iqbal', Ahmad Naeem Shahzad ${ }^{l}$, Shakeel Ahmad , \\ Zahid Mehmood Khan ${ }^{2}$, Naeem Sarwar ${ }^{\text {* }}$ \\ ${ }^{1}$ Department of Agronomy, Bahauddin Zakariya University Multan, Pakistan \\ ${ }^{2}$ Department of Agriculture Engineering, Bahauddin Zakariya University Multan, Pakistan \\ *Corresponding author: bajwa834@gmail.com.
}

Received: 06.01.2014

\begin{abstract}
Irrigation water is vital and most limiting input in arid agriculture. This study evaluates the late sown wheat crop under various agro-management practices for enhancing the crop productivity in water scarce area. Results exhibited that better leaf water relations expressed in terms of an improvement in the leaf water potential, leaf osmotic potential, stomatal conductance and relative water content of flag leaf as well as higher rates of transpiration and net $\mathrm{CO}_{2}$ assimilation were recorded with the planting technique of seed spreading augmented with furrows. This planting technique also expressed higher number of productive tillers, 1000grain weight and grain yield whereas lower soil penetration resistance as compared to other planting treatments. The highest water use efficiency (WUE) was achieved with the irrigation regime of $80 \%$ (evapotranspiration) ETo while in case of planting techniques, seed spreading augmented with furrows expressed the maximum values of WUE. The highest grain yield was recorded with flat sowing subjected to the irrigation equivalent to $100 \%$ reference evapotranspiration $(100 \%$ ETo) which was almost similar with seed spreading augmented with furrows at $80 \%$ ETo. Under deficit irrigation regimes $(80$ and $60 \%$ ETo), seed spreading augmented with furrows performed better than the other two planting techniques.
\end{abstract}

Key words: Planting techniques, grain yield, irrigation, water use efficiency and wheat

\section{INTRODUCTION}

In Pakistan, wheat is used as a staple food and is considered the largest grain crop of the country that contributes $12.5 \%$ to the value added in agriculture and $2.6 \%$ of gross domestic product (GDP). It was cultivated on an area of 8.7 million hectares with total production of 23.5 million tons, during 2011-12 (Anonymous, 2012). Yield potential of wheat crop is not being explored to its full extent and thus the average yield in Pakistan is even lower than its neighboring countries that may attributed to the sub-optimal management practices. In the cotton zone of Punjab province under cotton-wheat-cotton cropping pattern, due to late vacation of cotton fields only $20 \%$ of wheatis sown at the optimum sowing time, i.e. the first fortnightof November, while the remaining sowing is done from lateNovember (30\%) to December (50\%) (Khan et al. 2002).The late sowing of wheat crop is one of the major reasons of its low yield as it negatively effects the germination and emergence thus giving a weaker crop stand. It causes poor tillering due to winter injury in low temperature and also affects grain development (Haq and Khan, 2002) that lowers grain yield, consequently resulting in a yield loss of $39 \mathrm{~kg} \mathrm{ha}^{-1}$ day $^{-1}$ with delay of each day in sowing from the optimum planting time (Singh and Uttam, 1999). Seed priming can be employed to enhance the performance of late sown wheat (Farooq et al., 2008) as it improves speed and uniformity of germination, promotes synchronized emergence, eventually giving a better crop stand and final yield (Khanet al., 2011; Arif et al., 2008).

One of the most crucial factors restricting plant growth and consequently crop production in the world is water shortage as it constrains plant growth and production (Umar, 2006). This challenge of water scarcity has shifted crop production function from the land productivity concept to water productivity (Sarwar et al., 2013; Fereres and Soriano, 2007; Sarwar and Perry, 2002). Full irrigation to obtain better crop yield to cope with increasing food and fiber demands is no more a viable option for water scarce regions (Geerts et al., 2008a). Thus, a possible solution to this dilemma is deficit irrigation (Geerts et al., 2008b). The practice of applying irrigation water less than crop evapotranspiration demand with intent of imposing a managed level of water stress to the crop is considered as deficit or limited irrigation (Grant, 2008).

Pakistan's agriculture is exclusively based on irrigation water but unluckily per capita water availability has dropped dreadfully from $5260 \mathrm{~m}^{3}$ in 1951 to $1066 \mathrm{~m}^{3}$ in 2010 and is projected to be merely $870 \mathrm{~m}^{3}$ per capita 
by the year 2025 (Shaukat, 2011; Ahmad et al., 2009). In 2050, Pakistan's population is predicted to be 200 million that will demand $48 \%$ additional water thus, due to water shortage a reduction of ten million tons of food grains is being perceived (Javed, 2010). To address these challenges effectively we have to minimize the application losses of irrigation water to ensure availability of more water for crop production as well as to improve the crop water use efficiency that translates into "more crop per drop" of applied water. The sowing of wheat on raised beds and ridges is being adopted rapidly by the farmers in Mexico and many other countries. This method enhances the germination count, improves yield by $10 \%$ giving water saving of $30-50 \%$, along with the benefits of reduced lodging, increase in the efficiency of applied fertilizer and water, more water productivity, better utilization of solar radiation, and efficient drainage under high rainfall conditions (Ahmad et al., 2010; Sayre and Moreno-Ramos, 1997). In this study, performance of three planting techniques was compared under various irrigation regimes and an effort was made to develop environment and farmer friendly agro-technology package for sustainable wheat production under scarce water supplies in arid region of Punjab.

\section{MATERIALS AND METHODS}

\section{Crop husbandry}

The study was conducted for two consecutive crop growth seasons during 2007/08 and 2008/09 under field conditions at Research and Demonstration Farm, Regional Agricultural Economic Development Centre (RAEDC), Vehari, Pakistan $\left(30^{\circ} 1^{\prime} 0 \mathrm{~N}\right.$ and $71 \square 21^{\prime} 0 \mathrm{E}$ with altitude $135 \mathrm{~m}$ ) that falls under the arid region of southern Punjab (Arnon, 1992). The climate of the experimental site is characterized by hot dry summer and severe cold winter seasons (Fig.1).Water quality analysis was done before irrigation (Table-2).The experimental soil was clay loam having $\mathrm{pH} 8.4$, EC $256 \mu \mathrm{S} \mathrm{cm}^{-1}$ and organic matter $0.61 \%$ (Table-1). The analysis was done as per protocols mentioned in Hand Book No. 60 (US Salinity Lab. Staff, 1954) except available $P$ and soil texture, which were determined by the methods demonstrated by Watanabe and Olsen (1965) and Moodie et al. (1959), respectively.The experiment was laid out in randomized complete block design, replicated thrice and comprised of three planting techniques: $\mathrm{PT}_{1}$ (flat-drill planting in $11 \mathrm{~cm}$ apart rows), $\mathrm{PT}_{2}$. (bed-drill planting in $11 \mathrm{~cm}$ apart rows), $\mathrm{PT}_{3}$ (seed spreading augmented with furrows i.e. ridge planting) and three irrigation regimes namely $\mathrm{I}_{1}$ (Irrigation equal to $100 \%$ ETo), $I_{2}$ (Irrigation equal to $80 \%$ ETo) and $\mathrm{I}_{3}$ (Irrigation equal to $60 \%$ ETo). The experimental field having precision leveling was irrigated to the field capacity by applying heavy irrigation (locally called "rauni"). When the field reached the proper moisture condition (locally called "wattar"), seed bed was prepared by applying two ploughings followed by planking then beds were formed manually in case of $\mathrm{PT}_{2}$. A locally recommended wheat variety "Inqlab-91" was planted on December 19 during 2007/08 and on the same date during 2008/09. Seed hydroprimed for 12 hours was used at the rate of $150 \mathrm{~kg} \mathrm{ha}^{-1}$ in all the treatments.In case of $\mathrm{PT}_{1}$ crop was sown in flat field with the help of single row hand drill in rows $11 \mathrm{~cm}$ apart whereas, in case of $\mathrm{PT}_{2}$ the sowing was done on $33 \mathrm{~cm}$ wide raised beds. On the other hand in $\mathrm{PT}_{3}$,ridges were formed with help of a ridger after spreading seed uniformly in the field.Irrigation water was applied as in Ali et al., 2013 on the base of evapotranspiration method. Total applied water was recorded in all treatments for both years (Table-8). All other cultural practices were kept standard and uniform for all the treatments throughout the crop growth.

Table 1. Soil characteristics of the experimental site

\begin{tabular}{|c|c|c|c|c|}
\hline \multirow{2}{*}{ Characteristics } & & \multicolumn{3}{|c|}{ Depth (cm) } \\
\hline & & $0-15$ & $15-30$ & $30-45$ \\
\hline Organic matter (\%) & & 0.84 & 0.68 & 0.32 \\
\hline $\mathrm{pH}$ & & 8.4 & 8.4 & 8.5 \\
\hline $\mathrm{EC}\left(\mu \mathrm{S} \mathrm{cm} \mathrm{cm}^{-1}\right)$ & & 261 & 230 & 278 \\
\hline T.S.S. (\%) & & 0.87 & 0.14 & 0.14 \\
\hline Available-P (ppm) & & 8.2 & 6.5 & 5.8 \\
\hline Available-K (ppm) & & 235 & 180 & 125 \\
\hline \multirow[t]{2}{*}{ Saturation $\%$ age } & & 38 & 36 & 35 \\
\hline & Sand $(\%)$ & 29 & 30 & 29 \\
\hline \multirow[t]{2}{*}{ Soil separates } & Silt $(\%)$ & 39 & 35 & 35 \\
\hline & Clay (\%) & 32 & 35 & 36 \\
\hline Textural class & & Clay loam & Clay loam & Clay loam \\
\hline
\end{tabular}

\section{PARAMETERS STUDIED}

Relative water content (RWC \%): Five flag leaves were taken from each sub plot and fresh weight was recoded. Leaves were dipped in distilled water for 14-16 hours and saturated weight was noted after blotting off the excess water. Then after drying in an over at $80{ }^{\circ} \mathrm{C}$ for 48 hours, the dry weight of the same leaves was recorded and the relative water contents were calculated.

Leaf water potential $\left(\square_{w}\right)$ : For recoding leaf water potential $\left(\square_{\mathrm{w}}\right)$, randomly selected, fully expanded, three 
flag leaves were excised from each treatment and measurements were made from 8.00 am to 9.00 am with a water potential apparatus (Chas W. Cook Div., England).

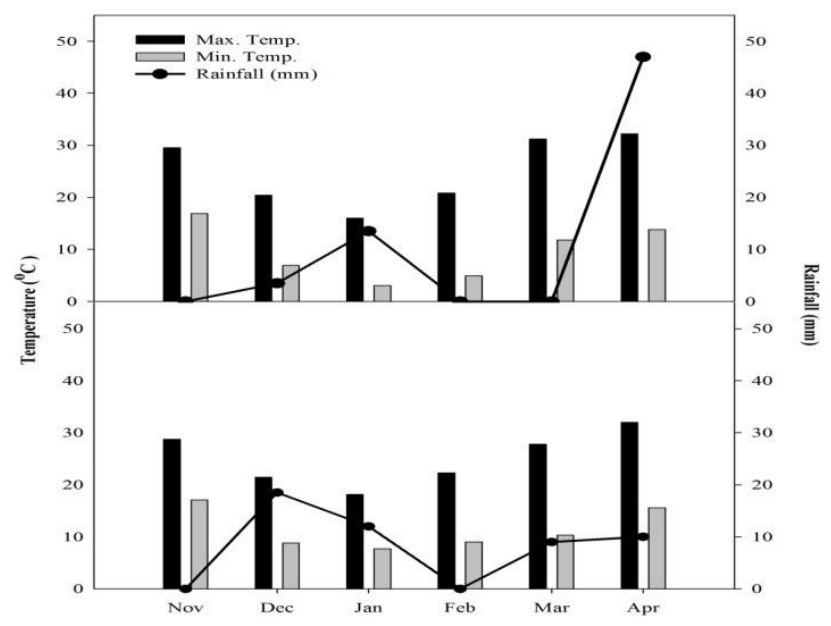

Fig.1. Climate data of growing seasons

Leaf osmotic potential $\left(\square_{s}\right)$ : The same leaves used for water potential were frozen at $-20{ }^{\circ} \mathrm{C}$ and were kept in Eppendoff tubes for a period of seven days then the cell sap was extracted and centrifuged @ 8000 rpm for 4 minutes. The sap was used for osmotic potential determination in a Vapor Pressure Osmometer (Wescor 5520, Logan, USA).

Table 2. Quality of irrigation water used during the entire course of studies

\begin{tabular}{lcc}
\hline Characteristics & Unit & Tube well water \\
\hline Electrical conductivity & $\mu \mathrm{S} \mathrm{cm}$ & 1165 \\
$\mathrm{pH}$ & & 7.55 \\
$\mathrm{Ca}^{2+}+\mathrm{Mg}^{+2}$ & $\mathrm{me} \mathrm{L}^{-1}$ & 7.82 \\
$\mathrm{Na}^{+}$ & $\mathrm{me} \mathrm{L}^{-1}$ & 3.08 \\
$\mathrm{CO}_{3}{ }^{-2}$ & $\mathrm{me} \mathrm{L}^{-1}$ & $\mathrm{Nil}$ \\
$\mathrm{HCO}_{3}{ }^{-}$ & $\mathrm{me} \mathrm{L}^{-1}$ & 5.3 \\
$\mathrm{Cl}^{-}$ & $\mathrm{me} \mathrm{L}^{-1}$ & 3.14 \\
$\mathrm{SO}_{4}^{-2}$ & $\mathrm{me} \mathrm{L}^{-1}$ & 1.12 \\
Sodium adsorption ratio & $(\mathrm{m} \mathrm{mol} \mathrm{L})^{-1.05}$ & 1.61 \\
Residual sodium carbonate & $\mathrm{me} \mathrm{L} \mathrm{L}^{-1}$ & $\mathrm{Nil}$ \\
\hline
\end{tabular}

Gas exchange parameters: The instantaneous measurements of net photosynthetic rate $\left(\mathrm{P}_{\mathrm{N}}\right)$, transpiration rate $(\mathrm{E})$ and leaf stomatal conductance $\left(\mathrm{g}_{\mathrm{s}}\right)$ were made on flag leaves of three plants, randomly selected from each experimental unit. Measurements were made from 9.00 am to 11.00 am using an open system portable infrared gas analyzer LCA 4 ADC (Analytical Development Company, Huddleston, England).

\section{Soil penetration resistance}

To measure the soil penetration resistance in the field cone penetrometer model CP20 (Agridry RIMIK Pty. Ltd., Toowoomba, Australia) was used. Detailed procedure is described as in Ali et al., 2013.

\section{Agronomic parameters}

Germination count $\left(\mathrm{m}^{2}\right)$ was recorded after seedlingemergence but before the start of tillering. At harvest a unit area of $1 \mathrm{~m}^{2}$ in each treatment at four differentlocations was selected and the total number of productivetillers was counted and then averaged. The crop was harvested at maturity, tied into bundles that were tagged, sun dried for a week and then threshedmanually. The grain yield per plot was recorded and then converted into $\mathrm{kg} \mathrm{ha}^{-1}$.A sample of one thousand grains was taken from each plot and weighed on an electrical balance (Model No. MJ500 Chyo, Japan) after drying at $70^{\circ} \mathrm{C}$ for 24 hours in an oven.

\section{Water use efficiency}

Water use efficiency was calculated by using the formula $W U E\left(\mathrm{~kg} \mathrm{ha}^{-1} \mathrm{~mm}^{-1}\right)=\frac{G Y}{T W A}$ Where, WUE is water use efficiency $\left(\mathrm{kg} \mathrm{ha}^{-1} \mathrm{~mm}^{-1}\right), \mathrm{GY}$ is grain yield $(\mathrm{kg}$ $\mathrm{ha}^{-1}$ ) and TWA is total water applied (mm).

\section{Statistical analysis}

The data was computed and analyzed by using MSTAT-C program (Russel and Eisensmith, 1983). Difference in means was computed by applying LSD at $\mathrm{P}<0.05$ (Steel et al.,1997).

\section{RESULTS}
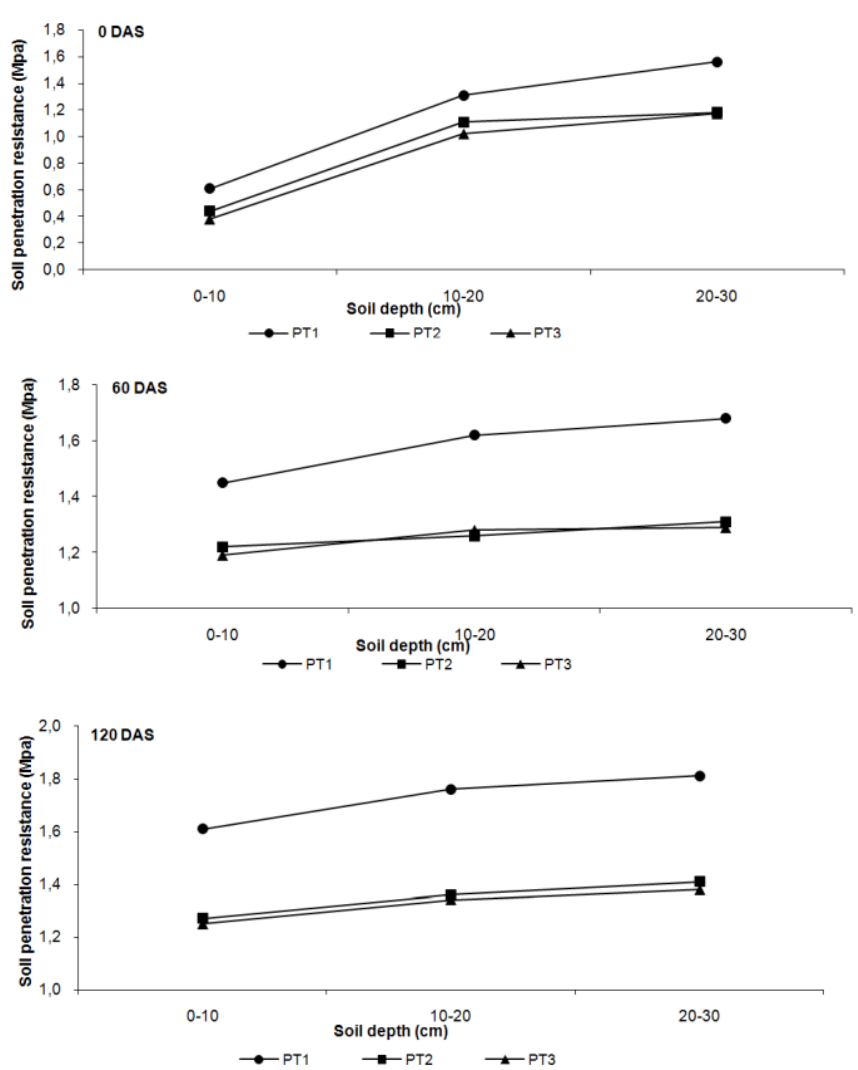

Fig.2. Soil penetration resistance (average of 2007-08 and 200809) measured at various soil depths under three planting techniques at different growth stages 


\section{Soil penetration resistance}

The influence of irrigation regimes on soil penetration resistance was found to be non-significant during both the crop growth seasons. The effect of planting techniques on this attribute averaged for 2007/08 and 2008/09 is presented in Fig.2. Significant differences $(\mathrm{P}<0.01)$ among different planting techniques showed that the highest values of soil penetration resistance were recorded with the treatment of flat planting while the minimum soil penetration resistance was offered by the treatment of seed spreading augmented with furrows. However, the treatments of bed planting and seed spreading augmented with furrows remained statistically at par with each other.

Data showed that at 0 days after sowing (DAS) soil penetration resistance measured at various soil depths differed significantly $(\mathrm{P}<0.01)$ from each other. Thus, the maximum soil penetration resistance of $1.30 \mathrm{MPa}$ was recorded at the soil depth of $20-30 \mathrm{~cm}$ that was followed by the soil penetration resistance measured at $10-20 \mathrm{~cm}$ soil depth. Whereas, significantly $(\mathrm{P}<0.01)$ the lowest value of $0.48 \mathrm{MPa}$ for soil penetration resistance was noted at the soil depth of $0-10 \mathrm{~cm}$. Data recorded at 60 DAS and 120 DAS showed that the various soil depths non-significantly influenced the soil penetration resistance (Fig.2).

\section{Leaf relative water content (\%)}

The highest leaf relative water content (RWC) of 85.94 and $92.77 \%$ during 2007/08 and 2008/09, respectively was estimated with the treatment of Irrigation $=100 \%$ ETo that was followed by the treatment of Irrigation $=80 \%$ ETo however, these two treatments were found to be statistically at par with each other. The data deciphered that during 2007/08, the maximum leaf RWCvalue of $87.51 \%$ was expressed by the crop plants subjected to the planting technique of seed spreading augmented with furrows that was followed by bed planting technique having leaf RWCvalue of $82.50 \%$ and the differences between them were found to be nonsignificant statistically. On the other hand, the lowest leaf relative water content of $74.30 \%$ was measured in the flag leaf of crop plants sown with flat planting treatment (Table-3)

\section{Leaf water potential (-MPa)}

Significantly $(\mathrm{P}<0.01)$ the lowest (more negative values) water potential of $-1.14 \mathrm{MPa}$ during 2007/08 was measured with the irrigation regime of $60 \%$ ETo that increased significantly $(\mathrm{P}<0.01)$ giving a value of -0.94 $\mathrm{MPa}$ when the irrigation level was raised from $60 \%$ ETo to $80 \%$ ETo but a further increment in the irrigation level showed no significant improvement in the leaf water potential. As regards planting techniques, the lowest value (more negative) of $-1.06 \mathrm{MPa}$ was noted with flat planting technique during 2007/08 that was followed by the leaf water potential value of-0.97 $\mathrm{MPa}$ recorded in case of bed planting treatment. Whereas, the maximum (less negative values) leaf water potential of $-0.93 \mathrm{MPa}$ was expressed by the flag leaves of crop planted under seed spreading augmented with furrows treatment (Table-3).

Table 3. Effect of planting techniques and irrigation regimes on RWC, leaf water potential and osmotic potential of wheat crop

\begin{tabular}{lcccccc}
\hline & \multicolumn{2}{c}{$\begin{array}{c}\text { Relative water content } \\
(\%)\end{array}$} & \multicolumn{2}{c}{$\begin{array}{c}\text { leaf water potential } \\
(-M P a)\end{array}$} & \multicolumn{2}{c}{$\begin{array}{c}\text { Leaf osmotic potential } \\
(-M P a)\end{array}$} \\
\hline Planting techniques & $2007-08$ & $2008-09$ & $2007-08$ & $2008-09$ & $2007-08$ & $2008-09$ \\
$\mathrm{PT}_{1}$ & $74.30 \mathrm{~b}$ & $81.00 \mathrm{~b}$ & $1.06 \mathrm{a}$ & $1.03 \mathrm{a}$ & $1.72 \mathrm{a}$ & $1.68 \mathrm{a}$ \\
$\mathrm{PT}_{2}$ & $82.50 \mathrm{a}$ & $89.04 \mathrm{a}$ & $0.97 \mathrm{ab}$ & $0.93 \mathrm{~b}$ & $1.54 \mathrm{~b}$ & $1.47 \mathrm{~b}$ \\
$\mathrm{PT}_{3}$ & $87.51 \mathrm{a}$ & $93.98 \mathrm{a}$ & $0.93 \mathrm{~b}$ & $0.89 \mathrm{~b}$ & $1.48 \mathrm{~b}$ & $1.42 \mathrm{~b}$ \\
$\mathrm{LSD}$ at 5\% & 6.203 & 6.294 & 0.089 & 0.070 & 0.122 & 0.152 \\
Irrigation (\% of ETo) & & & & & & \\
$\mathrm{I}_{1}$ & $85.94 \mathrm{a}$ & $92.77 \mathrm{a}$ & $0.88 \mathrm{~b}$ & $0.85 \mathrm{~b}$ & $1.38 \mathrm{~b}$ & $1.33 \mathrm{~b}$ \\
$\mathrm{I}_{2}$ & $83.59 \mathrm{a}$ & $90.30 \mathrm{a}$ & $0.94 \mathrm{~b}$ & $0.90 \mathrm{~b}$ & $1.47 \mathrm{~b}$ & $1.40 \mathrm{~b}$ \\
$\mathrm{I}_{3}$ & $74.79 \mathrm{~b}$ & $80.94 \mathrm{~b}$ & $1.14 \mathrm{a}$ & $1.11 \mathrm{a}$ & $1.88 \mathrm{a}$ & $1.82 \mathrm{a}$ \\
LSD at 5\% & 6.203 & 6.294 & 0.089 & 0.070 & 0.122 & 0.152 \\
\hline
\end{tabular}

\section{Leaf osmotic potential (-MPa)}

The highest values (less negative) of -1.38 and -1.33 $\mathrm{MPa}$ for leaf osmotic potential during 2007/08 and $2008 / 09$, respectively were achieved with the treatment of Irrigation $=100 \%$ ETo that was followed by the treatment of Irrigation $=80 \%$ ETo. The data revealed that during the crop growth season of 2007/08, the maximum (less negative) osmotic potential of $-1.48 \mathrm{MPa}$ was recorded with the treatment of seed spreading augmented with furrows that was followed by bedplanting treatment having the value of $-1.54 \mathrm{MPa}$ however, these two treatments remained statistically at par with each other. Whilst the lowest (more negative) value of osmotic potential $(-1.72 \mathrm{MPa})$ was expressed by the crop plants subjected to the flat planting technique (Table-3).

\section{Leaf stomatal conductance $\left(\mathrm{mol} \mathrm{m} \mathrm{m}^{-2} \mathrm{~s}^{-1}\right)$}

The highest stomatal conductance of $0.40 \mathrm{~mol} \mathrm{~m}^{-2} \mathrm{~s}^{-1}$ was expressed by the crop plants subjected to the irrigation regime of $100 \%$ ETo during 2007/08 whilst, the lowest value of $0.22 \mathrm{~mol} \mathrm{~m}^{-2} \mathrm{~s}^{-1}$ for stomatal conductance was noted with the treatment of Irrigation $=60 \%$ ETo. Seed spreading augmented with furrows showed the maximum stomatal conductance of $0.37 \mathrm{~mol} \mathrm{~m}^{-2} \mathrm{~s}^{-1}$ that was followed by the bed planting treatment having stomatal conductance of $0.34 \mathrm{~mol} \mathrm{~m} \mathrm{~m}^{-2} \mathrm{~s}^{-1}$, however, the 
differences between these treatments were found to be non-significant statistically. Whereas, the minimum stomatal conductance of $0.27 \mathrm{~mol} \mathrm{~m}^{-2} \mathrm{~s}^{-1}$ was recorded from the flag leaf of crop plants subjected to the flat planting technique. A similar picture emerged during the second crop growth season (Table-4).

Table 4. Effect of planting techniques and irrigation regimes on gas exchange parameters and root dry weight of wheat crop

\begin{tabular}{|c|c|c|c|c|c|c|c|c|}
\hline \multirow[b]{2}{*}{$\begin{array}{l}\text { Planting } \\
\text { techniques }\end{array}$} & \multicolumn{2}{|c|}{$\begin{array}{c}\text { Leaf stomatal } \\
\text { conductance } \\
\left(\mathrm{mol} \mathrm{m}^{-2} \mathrm{~s}^{-1}\right) \\
\end{array}$} & \multicolumn{2}{|c|}{ 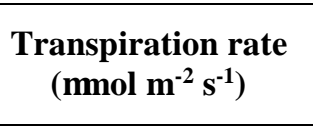 } & \multicolumn{2}{|c|}{$\begin{array}{l}\text { Net } \mathrm{CO}_{2} \text { assimilation } \\
\text { rate }\left(\mathrm{mmol} \mathrm{m}^{-2} \mathrm{~s}^{-1}\right)\end{array}$} & \multicolumn{2}{|c|}{$\begin{array}{l}\text { Root dry weight } \\
\qquad\left(\mathrm{g} \mathrm{cm}^{-3}\right)\end{array}$} \\
\hline & 2007-08 & 2008-09 & 2007-08 & 2008-09 & 2007-08 & 2008-09 & 2007-08 & 2008-09 \\
\hline $\mathrm{PT}_{1}$ & $0.27 b$ & $0.29 b$ & $1.68 \mathrm{c}$ & $1.79 b$ & $9.32 \mathrm{c}$ & $9.84 \mathrm{c}$ & $1.37 \mathrm{c}$ & $1.30 \mathrm{~b}$ \\
\hline $\mathrm{PT}_{2}$ & $0.34 \mathrm{a}$ & $0.36 \mathrm{~b}$ & $1.88 \mathrm{~b}$ & $1.99 \mathrm{a}$ & $12.01 \mathrm{~b}$ & $12.46 b$ & $1.90 \mathrm{~b}$ & $1.75 \mathrm{a}$ \\
\hline $\mathrm{PT}_{3}$ & $0.37 \mathrm{a}$ & $0.39 a$ & $2.02 \mathrm{a}$ & $2.12 \mathrm{a}$ & $13.34 \mathrm{a}$ & $13.77 \mathrm{a}$ & $2.06 \mathrm{a}$ & $1.87 \mathrm{a}$ \\
\hline $\begin{array}{l}\text { LSD at } 5 \% \\
\text { Irrigation ( } \% \\
\text { of ETo) }\end{array}$ & 0.031 & 0.032 & 0.099 & 0.152 & 0.766 & 0.672 & 0.145 & 0.167 \\
\hline $\mathrm{I}_{1}$ & $0.40 \mathrm{a}$ & $0.43 \mathrm{a}$ & $2.04 \mathrm{a}$ & $2.15 \mathrm{a}$ & $13.19 \mathrm{a}$ & $13.66 \mathrm{a}$ & 1.71 & 1.58 \\
\hline $\mathrm{I}_{2}$ & $0.37 b$ & $0.39 b$ & $1.98 \mathrm{a}$ & $2.10 \mathrm{a}$ & $12.43 \mathrm{a}$ & $13.01 \mathrm{a}$ & 1.80 & 1.66 \\
\hline $\mathrm{I}_{3}$ & $0.22 \mathrm{c}$ & $0.24 \mathrm{c}$ & $1.56 \mathrm{~b}$ & $1.65 b$ & $9.05 b$ & $9.40 \mathrm{~b}$ & 1.82 & 1.68 \\
\hline LSD at $5 \%$ & 0.031 & 0.032 & 0.099 & 0.152 & 0.766 & 0.672 & $\mathrm{~ns}$ & ns \\
\hline
\end{tabular}

\section{Transpiration rate $\left(\left[\mathrm{mol} \mathrm{m} \mathrm{m}^{-2} \mathrm{~s}^{-1}\right)\right.$}

The maximum transpiration rate of 2.04 and $2.15 \square \mathrm{mol}$ $\mathrm{m}^{-2} \mathrm{~s}^{-1}$ during 2007/08 and 2008/09, respectively was achieved by the crop plants to which irrigation was applied equivalent to $100 \%$ ETo and it was followed by the treatment of Irrigation $=80 \%$ ETo and these treatments remained statistically at par with each other. Whilst, significantly $(\mathrm{P}<0.01)$ the lowest transpiration rate of 1.56 and $1.65 \square \mathrm{mol} \mathrm{m}^{-2} \mathrm{~s}^{-1}$ during 2007/08 and 2008/09 was noted from the crop plants subjected to the irrigation regime of $60 \%$ ETo. Seed spreading augmented with furrows exhibited significantly $(\mathrm{P}<0.01)$ the highest value of $2.02 \square \mathrm{mol} \mathrm{m}^{-2} \mathrm{~s}^{-1}$ for transpiration rate whilst the lowest transpiration rate of $1.68 \square \mathrm{mol} \mathrm{m}^{-2} \mathrm{~s}^{-1}$ was recorded from the crop plants subjected to the flat planting treatment. Later on, during 2008/09, the maximum transpiration rate of $2.12 \square \mathrm{mol} \mathrm{m}^{-2} \mathrm{~s}^{-1}$ was achieved with the treatment of seed spreading augmented with furrows that was followed by bed planting treatment, however, the differences between them were found to be non-significant statistically. Again the minimum transpiration rate was noted with the flat planting treatment (Table-4).

\section{Net $\mathrm{CO}_{2}$ assimilation rate ( $\left(\left[\mathrm{mol} \mathrm{m} \mathrm{m}^{-2} \mathrm{~s}^{-1}\right)\right.$}

The highest values of 13.19 and $13.66 \square \mathrm{mol} \mathrm{m}^{-2} \mathrm{~s}^{-1}$ for net $\mathrm{CO}_{2}$ assimilation rate during 2007/08 and 2008/09, respectively were recorded with the treatment of Irrigation $=100 \%$ ETo that was followed by the treatment of Irrigation $=80 \%$ ETo however, these treatments remained statistically at par with each other. Whereas, significantly $(\mathrm{P}<0.01)$ the minimum net $\mathrm{CO}_{2}$ assimilation rate of 9.05 and $9.40 \square \mathrm{mol} \mathrm{m}^{-2} \mathrm{~s}^{-1}$ during 2007/08 and 2008/09, respectively was measured from the crop plants to which irrigation was applied equivalent to $60 \%$ ETo. While considering the planting techniques, seed spreading augmented with furrows treatment expressed significantly
$(\mathrm{P}<0.01)$ the maximum net $\mathrm{CO}_{2}$ assimilation rate of 13.34 $\square \mathrm{mol} \mathrm{m} \mathrm{m}^{-2} \mathrm{~s}^{-1}$ during 2007/08 that was followed by bed planting technique having net $\mathrm{CO}_{2}$ assimilation rate of 12.01 $\square \mathrm{mol} \mathrm{m}^{-2} \mathrm{~s}^{-1}$. While the lowest value of $9.32 \square \mathrm{mol}$ $\mathrm{m}^{-2} \mathrm{~s}^{-1}$ for net $\mathrm{CO}_{2}$ assimilation rate was recorded with the treatment of flat planting (Table-4).

\section{Germination count and tillers $\left(\mathrm{m}^{-2}\right)$}

The highest number of seedlings was counted in flat planting treatment that was followed by bed planting during 2007/08 and 2008/09 however;the differences between these two treatments were found to be nonsignificant statistically while the lowest germination count $\mathrm{m}^{-2}$ was recorded with the treatment of seed spreading augmented with furrows. The treatment of seed spreading augmented with furrowsduring both the years produced significantly $(\mathrm{P}<0.01)$ the maximum number tillers plant ${ }^{-1}$ that was followed by flat planting treatment whereas, as the minimum number oftillers plant ${ }^{-1}$ was counted with the treatment of bed planting. As regards the tillers $\mathrm{m}^{-2}$, the highest number of tillers $\mathrm{m}^{-2}$ was produced by the treatment of flat planting that was followed by seed spreading augmented with furrows while the minimum number of tillers $\mathrm{m}^{-2}$ was counted in case of bed planting treatment. However, the differences between the treatments of bed planting and seed spreading augmented with furrows were found to be non-significant statistically.A significant $(\mathrm{P}<0.01)$ impact of planting techniques on number of unproductive tillers $\mathrm{m}^{-2}$ was noted during the both crop growth seasons. Thus, significantly $(\mathrm{P}<0.01)$ the highest number of 30.9 unproductive tillers during 2007/08 was recorded with the flat planting treatment that was followed by bed planting technique which produced 21.4 unproductive tillers $\mathrm{m}^{-2}$. Whilst, the lowest number of 19.54 unproductive tillers was noted in case of seed spreading augmented with furrows, however, it remained statistically at par with the 
treatment of bed planting. Almost a similar trend was observed during the second crop growth season(Table-6).

\section{Number of productive tillers $m^{-2}$}

The highest number of 278.5 productive tillers $\left(\mathrm{m}^{-2}\right)$ was achieved with the treatment Irrigation $=100 \%$ ETo that was followed by the tiller number of $270.6 \mathrm{~m}^{-2}$ recorded with the treatment of Irrigation $=80 \%$ ETo and the differences between these two treatments were found to be non-significant statistically. While significantly $(\mathrm{P}<0.01)$ the lowest number of productive tillers $237.7 \mathrm{~m}^{-2}$ was counted with the treatment where irrigation was applied equivalent to $60 \%$ ETo. Effect of planting techniques showed that the maximum number of 276.7 and $318.3 \mathrm{~m}^{-2}$ productive tillers $\mathrm{m}^{-2}$ during 2007/08 and 2008/09, respectively were recorded with the flat planting treatment that was followed by the treatment of seed spreading augmented with furrows but the differences between these treatments were not significant statistically. Whereas, the bed planting treatment produced significantly $(\mathrm{P}<0.01)$ the lowest number of 244.1 and 277.8 productive tillers during 2007/08 and 2008/09, respectively (Table-5).The interactions between irrigation regimes and planting techniques were found to be significant $(\mathrm{P}<0.05)$ during both the crop growth seasons. Thus, the highest number of productive tillers (305.33) was producedby the crop plants subjected to the irrigation regime of $100 \%$ ETo along with flat planting technique (Table-7).

Table 5. Effect of planting techniques and irrigation regimes on productive tillers, 1000-grain weight and of wheat crop

\begin{tabular}{|c|c|c|c|c|c|c|c|c|}
\hline \multirow{2}{*}{ Planting techniques } & \multicolumn{2}{|c|}{$\begin{array}{l}\text { Productive } \\
\text { tillers }\left(\mathbf{m}^{-2}\right)\end{array}$} & \multicolumn{2}{|c|}{ 1000-Grains weight $(\mathrm{g})$} & \multicolumn{2}{|c|}{ Grain yield $\left(\mathrm{kg} \mathrm{ha}^{-1}\right)$} & \multicolumn{2}{|c|}{$\begin{array}{c}\text { Water use efficiency } \\
\left(\mathrm{kg} \mathrm{ha}^{-1} \mathbf{~ m m}^{-1}\right)\end{array}$} \\
\hline & $2007-08$ & 2008-09 & $2007-08$ & 2008-09 & $2007-08$ & 2008-09 & $2007-08$ & 2008-09 \\
\hline $\mathrm{PT}_{1}$ & $277 \mathrm{a}$ & $318 \mathrm{a}$ & $35.29 b$ & $37.2 b$ & $3609 b$ & $4007 \mathrm{ab}$ & $20.11 b$ & $19.95 b$ \\
\hline $\mathrm{PT}_{2}$ & $244 b$ & $278 b$ & $37.00 \mathrm{ab}$ & $39.9 \mathrm{ab}$ & $3535 b$ & $3815 b$ & $20.12 b$ & $19.45 b$ \\
\hline $\mathrm{PT}_{3}$ & $266 \mathrm{a}$ & $301 \mathrm{a}$ & $38.18 \mathrm{a}$ & $41.0 \mathrm{a}$ & $4035 \mathrm{a}$ & $4333 a$ & $23.22 \mathrm{a}$ & $22.33 \mathrm{a}$ \\
\hline LSD at $5 \%$ & 16.08 & 18.49 & 2.161 & 2.78 & 311.21 & 348.70 & 1.727 & 1.622 \\
\hline \multicolumn{9}{|l|}{ Irrigation ( $\%$ of ETo) } \\
\hline $\mathrm{I}_{1}$ & $278 \mathrm{a}$ & $317 \mathrm{a}$ & $38.47 \mathrm{a}$ & $41.0 \mathrm{a}$ & $4262 \mathrm{a}$ & $4676 a$ & $19.48 b$ & $19.29 b$ \\
\hline $\mathrm{I}_{2}$ & $271 \mathrm{a}$ & $309 a$ & $37.37 \mathrm{a}$ & $40.0 \mathrm{a}$ & $3923 b$ & $4239 b$ & $22.07 \mathrm{a}$ & $21.39 \mathrm{a}$ \\
\hline $\mathrm{I}_{3}$ & $238 b$ & $271 b$ & $34.63 \mathrm{~b}$ & $37.1 \mathrm{~b}$ & $2994 c$ & $3239 \mathrm{c}$ & $21.90 \mathrm{a}$ & $21.05 \mathrm{a}$ \\
\hline LSD at $5 \%$ & 16.08 & 18.89 & 2.161 & 2.78 & 311.21 & 348.70 & 1.727 & 1.622 \\
\hline
\end{tabular}

Table 6. Efect of planting techniques on germination count m-2, tillers plant-1,tillers m-2 and un-productive tillers m-2of wheat crop

\begin{tabular}{lcccccccc}
\hline & \multicolumn{3}{c}{${\text { Germination count } \mathbf{~ m}^{-2}}^{\text {Tillers }}$} & \multicolumn{2}{c}{ plant $^{-1}$} & \multicolumn{2}{c}{ Tillers $^{-2}$} & \multicolumn{2}{c}{ Un-productive tillers $^{-2}$} \\
\hline Planting techniques & $2007-08$ & $2008-09$ & $2007-08$ & $2008-09$ & $2007-08$ & $2008-09$ & $2007-08$ & $2008-09$ \\
$\mathrm{PT}_{1}$ & 143.15 & 155.87 & 2.15 & 2.34 & 307.60 & 364.74 & 30.86 & 46.48 \\
$\mathrm{PT}_{2}$ & 141.19 & 147.91 & 1.88 & 2.06 & 265.44 & 304.68 & 21.39 & 26.86 \\
$\mathrm{PT}_{3}$ & 112.87 & 120.11 & 2.53 & 2.61 & 285.56 & 313.49 & 19.54 & 12.14 \\
$\mathrm{LSD}$ at 5\% & 19.242 & 25.060 & 0.238 & 0.372 & $\mathrm{~ns}$ & 47.933 & 4.488 & 7.510 \\
\hline
\end{tabular}

\section{0-grain weight $(g)$}

Significantly $(P<0.01)$ the heaviest grains of $38.47 \mathrm{~g}$ were produced during 2007/08 with the irrigation regime of $100 \%$ ETo that was followed by the treatment of Irrigation $=80 \%$ ETo having 1000 -grain weight of 37.37 $\mathrm{g}$ but the difference between these two treatments was found to be non-significant statistically. Whereas, the minimum 1000-grain weight of $34.63 \mathrm{~g}$ was measured from the crop plants subjected to the irrigation equivalent to $60 \%$ ETo. In case of planting techniques, seed spreading augmented with furrows showed the best performance during both the crop growth seasons by producing the heaviest grains of 38.18 and $41.00 \mathrm{~g}$ during $2007 / 08$ and 2008/09, respectively however, it remained statistically at par with bed planting treatment which presented 37.00 and $39.94 \mathrm{~g}$ weight of 1000-grains during 2007/08 and 2008/09, respectively. While significantly $(\mathrm{P}<0.01)$ the lowest 1000-grain weight of 35.29 and 37.17 g during 2007/08 and 2008/09, respectively was produced with the flat planting technique (Table-5).
Table 7. Interactive effect of planting techniques and irrigation regimes on productive tillers and grain yield of wheat crop

\begin{tabular}{lllll} 
& \multicolumn{2}{c}{$\begin{array}{c}\text { Productive } \\
\text { tillers }\left(\mathbf{m}^{-2}\right)\end{array}$} & \multicolumn{2}{c}{$\begin{array}{c}\text { Grain yield } \\
(\mathbf{k g ~ h a})\end{array}$} \\
\hline Interactions & $2007-08$ & $2008-09$ & $2007-08$ & $2008-09$ \\
$\mathrm{PT}_{1} \times \mathrm{I}_{1}$ & $305 \mathrm{a}$ & $351 \mathrm{a}$ & $4481 \mathrm{a}$ & $5098 \mathrm{a}$ \\
$\mathrm{PT}_{2} \times \mathrm{I}_{1}$ & $257 \mathrm{~cd}$ & $293 \mathrm{~cd}$ & $3996 \mathrm{a} \sim$ & $4308 \mathrm{bc}$ \\
$\mathrm{PT}_{3} \times \mathrm{I}_{1}$ & $273 \mathrm{bc}$ & $308 \mathrm{bc}$ & $4310 \mathrm{ab}$ & $4624 \mathrm{ab}$ \\
$\mathrm{PT}_{1} \times \mathrm{I}_{2}$ & $294 \mathrm{ab}$ & $338 \mathrm{ab}$ & $3888 \mathrm{bcd}$ & $4239 \mathrm{bc}$ \\
$\mathrm{PT}_{2} \times \mathrm{I}_{2}$ & $250 \mathrm{cde}$ & $285 \mathrm{cde}$ & $3702 \mathrm{~cd}$ & $3994 \mathrm{c}$ \\
$\mathrm{PT}_{3} \times \mathrm{I}_{2}$ & $267 \mathrm{bc}$ & $303 \mathrm{c}$ & $4179 \mathrm{ac}$ & $4486 \mathrm{bc}$ \\
$\mathrm{PT}_{1} \times \mathrm{I}_{3}$ & $231 \mathrm{de}$ & $266 \mathrm{de}$ & $2459 \mathrm{e}$ & $2685 \mathrm{~d}$ \\
$\mathrm{PT}_{2} \times \mathrm{I}_{3}$ & $224 \mathrm{e}$ & $256 \mathrm{e}$ & $2910 \mathrm{e}$ & $3146 \mathrm{~d}$ \\
$\mathrm{PT}_{3} \times \mathrm{I}_{3}$ & $258 \mathrm{~cd}$ & $293 \mathrm{~cd}$ & $3616 \mathrm{~d}$ & $3889 \mathrm{c}$ \\
$\mathrm{LSD}_{3}$ at $5 \%$ & 27.85 & 32.02 & 539.03 & 602.22 \\
\hline
\end{tabular}

\section{Grain yield $\left(\mathrm{kg} \mathrm{ha}^{-1}\right)$}

Improved grain yield of $4262.2 \mathrm{~kg} \mathrm{ha}^{-1}$ was achieved with the treatment of Irrigation $=100 \%$ ETo that was followed by the treatment of Irrigation $=80 \%$ ETo which 
produced $3922.6 \mathrm{~kg} \mathrm{ha}^{-1}$ of grains during year of 2007/08. As regards planting techniques, significantly $(\mathrm{P}<0.01)$ the highest grain yield of $4034.9 \mathrm{~kg} \mathrm{ha}^{-1}$ was recorded with the treatment of seed spreading augmented with furrows. Whilst, the bed planting treatment secured the bottom rank by producing the minimum grain yield of $3534.94 \mathrm{~kg} \mathrm{ha}^{-1}$ (Table-5). The interactions between irrigation regimes and planting techniques were found to be significant $(\mathrm{P}<0.01$ and $\mathrm{P}<0.05)$ during both the crop growth seasons. These significant effects might be associated to the better performance of flat planting treatment during both the crop growth seasons at the highest irrigation level of $100 \%$ ETo than other planting techniques but under the lower irrigation regime i.e $60 \%$ ETo its response was significantly reduced than the treatments of bed planting and that of seed spreading augmented with furrows. It was also noted that reducing the irrigation level from $80 \%$ EToto $60 \%$ ETo resulted in a significant decline in the grain yield of flat planting treatment (Table-7).

Table8. Amount of water applied and rainfall during crop seasons

\begin{tabular}{cccc}
\hline \multicolumn{3}{c}{$\mathbf{2 0 0 7 - 0 8}$} \\
\hline & Irrigation (mm) & Rainfall $(\mathbf{m m})$ & Total $(\mathbf{m m})$ \\
\hline $\mathrm{I}_{1}$ & 205.31 & 13.50 & 218.81 \\
$\mathrm{I}_{2}$ & 164.25 & 13.50 & 177.75 \\
$\mathrm{I}_{3}$ & 123.19 & 13.50 & 136.69 \\
\hline \multicolumn{4}{c}{$\mathbf{2 0 0 8 - 0 9}$} \\
\hline $\mathrm{I}_{1}$ & Irrigation (mm) & Rainfall (mm) & Total $(\mathbf{m m})$ \\
$\mathrm{I}_{2}$ & 221.45 & 21.00 & 242.45 \\
$\mathrm{I}_{3}$ & 177.16 & 21.00 & 198.16 \\
\hline & 132.87 & 21.00 & 153.87 \\
\hline
\end{tabular}

There was a strong and linear relationship of grain yield with the number of productive tillers $\mathrm{m}^{-2}$ and 1000 grain weight. The regression accounted for 68.9 and $81.9 \%$, respectively variance in grain yield for the above mentioned yield components, respectively during 2007/08 while the corresponding figures for the year 2008/09 were 66.2 and $58.5 \%$, respectively (Fig.3, 4).

\section{Water use efficiency}

The highest water use efficiency of $22.07 \mathrm{~kg} \mathrm{ha}^{-1} \mathrm{~mm}^{-1}$ was achieved by the crop plants irrigated at the rate of $80 \%$ ETo that was followed by the treatment of Irrigation $=60 \%$ ETohowever, these treatments remained statistically at par with each other. Whereas, significantly $(\mathrm{P}<0.01)$ the lowest water use efficiency of $19.48 \mathrm{~kg} \mathrm{ha}^{-1}$ $\mathrm{mm}^{-1}$ was recorded with the irrigation treatment of $100 \%$ ETo. The highest water use efficiency of $23.22 \mathrm{~kg} \mathrm{ha}^{-1}$ $\mathrm{mm}^{-1}$ during 2007/08 was measured with the treatment of seed spreading augmented with furrows and it was followed by bed planting technique having the WUE value of $20.12 \mathrm{~kg} \mathrm{ha}^{-1} \mathrm{~mm}^{-1}$. While the minimum water use efficiency of $20.11 \mathrm{~kg} \mathrm{ha}^{-1} \mathrm{~mm}^{-1}$ was noted from the crop plants subjected to the flat planting treatmentand the differences between the treatments of bed planting and flat planting were found to be non-significant statistically. A similar trend was noted during the second crop growth season (Table-5).

\section{DISCUSSION}

In this study comparatively lower germination count was recorded with seed spreading augmented with furrows planting technique as compared to flat planting that might have taken place due to possible deep placement of few seeds in seed spreading augmented with furrows planting treatment which affected the germination count. However, this treatment exhibited an excellent compensation for lower plant population by expressing a better tillering potential and producing a lesser number of parasite tillers (i.e. unfertile tillers) that was probably associated to the increased soil surface area of the parabolaof the ridge and the seeds got spread uniformly all over the parabola resulting in more space available to each plant. While, bed-drill planting showed better germination count but gave poor tillering against the seed spreading augmented with furrows treatment that might be related to a higher in-row inter-plant competition, as the more seeds were placed in each row due to reduced number of rows per unit area (Waraich, 2006).
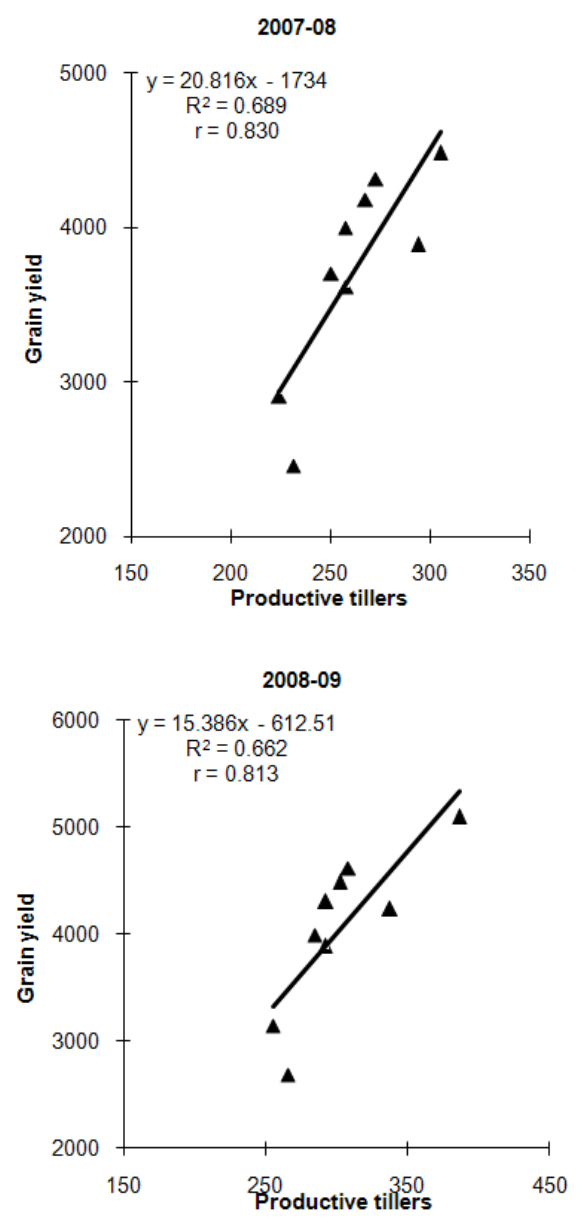

Fig.3. Relationship between grain yield and productive tillers

Moreover, the enhanced crop growth and higher grain yield might be linked to the improved soil physical conditions in case of seed spreading augmented with furrows planting technique resulting in lower soil compaction, reduced root penetration resistance, enhanced soil porosity, aeration and water holding capacity that encouraged better root proliferation thus giving rise to 
vigorous plants which were less prone to lodging. Consequently, higher water use efficiency was recorded with the planting techniques of seed spreading augmented with furrows and that of bed planting as compared to the flat planting technique (Amin et al. 2006; Waraich, 2006; Tripathi et al., 2005; Aggarwal and Goswami, 2003). In addition to the above mentioned factors, this improvement in water use efficiency might also be endorsed to the better availability of plant nutrients in ridges, the lower weed density and weed biomass, and ultimately an enhanced final crop yield (Nasrullah et al., 2009).
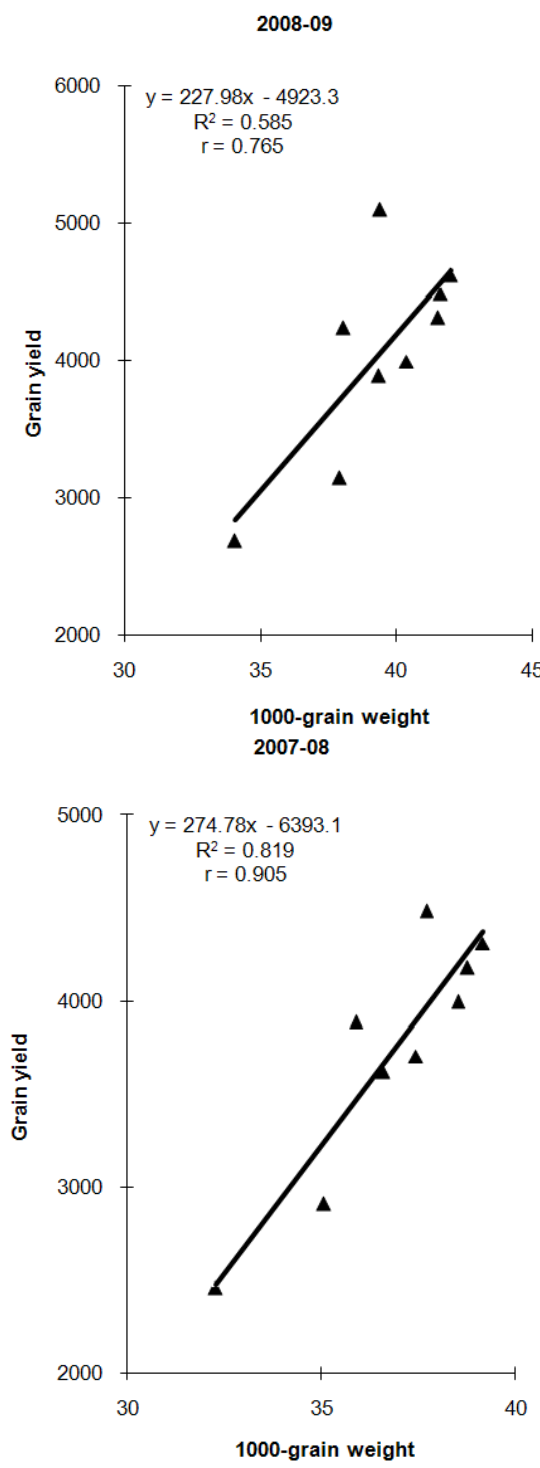

Fig.4. Relationship between grain yield and 1000-grain weight

Leaf water potential has a vital significance for its association to the cell turgor pressure and osmotic potential. It was observed that during both crop growth seasons, the leaf water potential, osmotic potential and relative water content dropped linearly with decreasing irrigation levels from $100 \%$ ETo to $60 \%$ ETo. This reduction in these attributes might have caused partial closure of stomata that resulted in a significant decrease in stomatal conductance which limited the access of photosynthetic apparatus to $\mathrm{CO}_{2}$ thus having pronounced effect on net $\mathrm{CO}_{2}$ assimilation rate. Heaton and Tallman (1987) also reported a decrease in stomatal conductance due to water deficit. Moisture stress due to limited irrigation possibly caused a decline in water absorption by the roots subsequently decreasing the rate of transpiration. In this study the treatments of seed spreading augmented with furrows and that of bed planting provided more favorable soil conditions for root growth including lower penetration resistance thus enhanced root biomass that might have promoted the absorption of soil moisture hence increasing the leaf water potential and relative water content which boosted stomatal conductance that consequently promoted transpiration rate which encouraged net $\mathrm{CO}_{2}$ assimilation rate and finally a higher biomass production as well as crop yield.

In the study, it was observed that each incremental irrigation from 60 to $100 \%$ ETo improved the yield and yield components as well as physiological attributes of wheat crop sown under flat planting technique. While, under the planting technique of seed spreading augmented with furrows the aforementioned parameters increased significantly by increasing the irrigation level from $60 \%$ ETo to $80 \%$ ETo but an additional increment in irrigation beyond this point (from 80 to $100 \%$ ETo) showed no significant enhancement in majority of the said attributes. This indicates that wheat crop can be grown more successfully with a lesser quantity of irrigation water (irrigation equal to $80 \%$ ETo) under seed spreading augmented with furrows planting method as compared to the flat planting. Erekul et al. (2012) recorded highest wheat yield and quality with $80 \mathrm{~mm}$ irrigation regime. Pierre et al.(2008) also observed non-significant differences in wheat total dry matter accumulation, kernel weight and diameter, and grain yield by decreasing the irrigation level from $100 \%$ ETo to $80 \%$ ETo whereas, a further decrease in irrigation caused a decline in grain yield. Our results are in line with the findings of other scientists Zhang et al. (2002)who also reported a decrease in WUE with increasing amount of irrigation but yield increased. Our findings are also endorsed by the results of Xue et al. (2006) and Mehmood et al. (1999).

\section{CONCLUSION}

Keen perusal of the results revealed that seed spreading augmented with furrows along with application of water equivalent to $80 \%$ ETo proved to be better strategy for efficient utilization of water input under arid climate for sustainable wheat crop production.

\section{LITERATURE CITED}

Aggarwal, P. and B. Goswami. 2003. Bed planting system for increasing water use efficiency of wheat grown on Inceptisol (TypicUstochrept). Ind. J. Agri.Sci. 73: 422-25.

Ahmad, M.,A. Ghafoor,M. Asif, and H.U. Farid.2010. Effect of irrigation techniques on wheat production and water saving in soils. Soil Environ. 29: 69-72.

Ahmad, S., A. Ahmad, M. Zial-ul-Haq, H. Ali, T. Khaliq, M.A. Anjum,M.A. Khan, A. Hussain and G.Hoogenboom. 2009. Resource use efficiency of field grown transplanted rice 
(Oryza sativa $\mathrm{L}$ ) under irrigated semi-arid environment. J. Food Agri. Environ.7: 487-492.

Ali, H.N. Iqbal, S. Ahmad, A.N. Shahzad and N. Sarwar.2013. Performance of late sown wheat crop under different planting geometries and irrigation regimes in arid climate. Soil Till Res. 130: 109-119.

Amin, M., A. Razzaq, Rehmatullah, M. Ramzan.2006. Effect of planting methods, seed density and nitrogen phosphorus (NP) fertilizer levels on sweet corn (Zea mays L.). J. Res. Sci. 17: 83-89.

Anonymous.2012. Economic Survey of Pakistan 2010-11. Ministry of Food, Agriculture and Livestock.Govt. of Pakistan, Finance Division, Economic Advisor's Wing, Islamabad.p.16-17.

Arif, M., M.T. Jan, K.B. Marwat, M.A. Khan. 2008. Seed priming improves emergence and yield of soybean.Pakistan J. Bot. 40:1169-1177.

Arnon, I. 1992.Agriculture in dry lands-principles and practices.Developments in agricultural and managed forest ecology No. 26. Elsevier Science Publishers B.V. Molenwerf 1, Amesterdam, The Netherland. p. 21-23, 742.

Erekul, U., K. P. Gotz, T.Gurbuz. 2012. Effect of supplemental irrigation on yield and bread making quality of wheat (Triticumaestivum L.) varieties under the mediterranean climate condition. Turk. J. Field Crops. 17: 78-86.

Farooq, M.S., M.A. Basra, H. Rehman andB.A. Saleem.2008. Seed priming enhances the performance of late sown wheat (Triticmaestivum L.) by improving chilling. J.Agron. Crop Sci. 194: 55-60.

Fereres, E., and M.A. Soriano MA. 2007. Deficit irrigation for reducing agricultural water use. J. Exp. Bot. 58: 147-159.

Grant, S.2008.Regulated deficit irrigation.In Progressive Viticulture, Mid Valley Agricultural Services. www.progressiveviticulture.com/CSUF_RDI_08.pdf (accessed June 10, 2009).

Geerts, S., D. Raes, N. Garcia, J. Vacher, R. Mamani, J. Mendoza, R. Huanca, B. Morales, R. Miranda, J. Cusicanqui andC. Taboada. 2008a. Introducing deficit irrigation to stabilize yields of quinoa (Chenopodium quinoaWilld.). Eur. J.Agron. 28: 427-436.

Geerts, S., D. Raes, N. Garcia, O. Condori, J. Mamani, R. Miranda, J. Cusicanqui, C. Taboada, E. Yucra andJ. Vacher. 2008b.Could deficit irrigation be a sustainable practice for quinoa (Chenopodium quinoaWilld.) in the Southern Bolivian Altiplano? Agri. Water Manage. 95: 909-917.

Haq, N. U., and M. Khan.2002. Effect of planting date, chlortoluran+MCPA and wheat varieties on weed control and wheat yield. Sarhad J.Agri. 18: 433-447.

Heaton, T., A. Lee,G. Tallman. 1987. Stomata in senescing leaves: Guard cell viability and regulation of stomatal function in Nicotianaglawa. In: Thomson WW, Nothnagel EE, HuffakerRC.editors, Plant Senescence: Its Biochemistry and Physiology. p. 182-214. American Society of Plant Physiologists, Rockville, MD.

Javed, S. 2010. 22 ${ }^{\text {nd }}$ March World Water Day (In Urdu). Daily Khabrain, Multan. 22March 2010. p. 4.

Khan, M.A., Ahmad,N., Khan, M.A. andSikandar, Z. (2002) Wheat plantingpattern in Punjab and its economic implications. J. Agric. Res. 40: 249-258.

Khan, M.B., M.A. Gurchani, M. Hussain, S. Fareed andK. Mahmood.2011. Wheat seed enhancement by vitamin and hormonal priming. Pakistan J. Bot. 43: 1495-11499.

Mehmood, N., K. Hussain and M. Saeed.1999. Irrigation techniques for efficient use of irrigation water in wheat and cotton. J. Drain. Water Manage. 31: 22-27.
Moodie, C.D., H.W. Smith,P.R. McCreey. 1959. Laboratory manual of soil fertility. Staff College of Washington, D.C., U.S.A, p. 175.

Nasrullah, H.M., M.S. Cheema andM. Akhtar.2009. Efficiency of different dry sowing methods to enhance wheat yiled under cotton-wheat cropping system. Intl. Conference on Sustainable Food Grain production-Challenges and Opportunities.Oct. 26-27, 2009, Univ. Agric.Fsd. Pakistan p. 66.

Pierre, C.S., C.J.Peterson, A.S. Ross, J. Ohm, M.C. Verhoeven, M. Larson andB. Hoefer.2008. White wheat grain quality changes with genotype, nitrogen fertilization, and water stress. Agron. J. 100: 414-420.

Russel, D.F. and S.P. Eisensmith.1983. MSTAT MicroComputer statistical programme, Crop and Soil Science Deptt., Michigan State University, Michigan State, Esat Lansing, Michigan, USA.

Sarwar, N., H. Ali, M. Maqsood, E. Ullah, M. Shahzad, K. Mubeen, A. N. Shahzad, M. A. Shahid, and S. Ahmad. "Phenological response of rice plants to different micronutrimentsapplication under water saving paddy fields on calcareous soil." Turk. J. Field Crops. 18: 52-57.

Sarwar, A. and C. Perry. 2002. Increasing water productivity through deficit irrigation: Evidence from the Indus plains of Pakistan. Irri.Drain. 51: 87-92.

Sayre, K.D. and O.H. Moreno-Ramos.1997. Applications of raised-bed planting systems to wheat. Wheat Program Special Rep. 31, Mexico, DF, CIMMYT.

Shaukat, S. 2011. India Plays the Water Card.<http://www.markthetruth.com/current-affairs/446india-plays-the-water-card.html> (accessed on 28 Feb 2012).

Singh, V.P.N. and S.K. Uttam.1999. Influence of sowing dates on yield of wheat cultivars under saline sodic conditions in Central Utter Pradesh. Indian Agri. 38: 64-68.

Steel, R.G.D., J.H. Torrie and D.A.Dickey.1997. Principles and procedures of statistics. McGraw Hill Book Co., Inc New York, USA.

Tripathi, S.C., K.D. Sayre, J.N. Kaul. 2005. Planting systems on lodging behavior, yield components, and yield of irrigated spring bread wheat. Crop Sci. 45: 1448-1455.

US Salinity Lab. Staff.1954. Diagnosis and improvement of saline alkaline soil. USDA Hand Book No. 60, Washington, D.C. p. 160.

Umar, S. 2006. Alleviating adverse effects of water stress on yield of sorghum, mustard and groundnut by potassium application. Pakistan J. Bot. 38: 1373-1380.

Waraich, E. A. 2006. Crop management strategies to improve water use efficiency in irrigated wheat. Ph.D Thesis, DeptAgronUnivAgricFsd Pakistan p. 3.

Watanabe, F.S. andS.R. Olsen.1965. Test of an ascorbic acid method for determining phosphorus in water and bicarbonate extracts from soil. Soil Sci. Society America Proceeding. 29: 677-678.

Xue, Q., Z. Zhu, J.T. Muscik, B.A. Stewart,D.A. Dusek. 2006. Physiological mechanisms contributing to the increased water use efficiency in winter wheat under deficit irrigation. J. Plant Phys. 163: 154-164.

Zhang, Y.Q., C.M. Liu, Y.J. Shen, A. Kondoh, C.Y. Tang, T. Tanaka andJ. Shimada.2002. Measurement of evapotranspiration in a winter wheat field. Hydrol.Pro. 16: 2805-2817. 